\title{
At a critical juncture? Change and continuity in the institutional development of the Council Secretariat
}

Citation for published version (APA):

Christiansen, T., \& Vanhoonacker, S. M. R. L. (2008). At a critical juncture? Change and continuity in the institutional development of the Council Secretariat. West European Politics, 31, 751-770.

https://doi.org/10.1080/01402380801906015

Document status and date:

Published: 01/01/2008

DOI:

10.1080/01402380801906015

Document Version:

Publisher's PDF, also known as Version of record

Document license:

Taverne

Please check the document version of this publication:

- A submitted manuscript is the version of the article upon submission and before peer-review. There can be important differences between the submitted version and the official published version of record.

People interested in the research are advised to contact the author for the final version of the publication, or visit the DOI to the publisher's website.

- The final author version and the galley proof are versions of the publication after peer review.

- The final published version features the final layout of the paper including the volume, issue and page numbers.

Link to publication

\footnotetext{
General rights rights.

- You may freely distribute the URL identifying the publication in the public portal. please follow below link for the End User Agreement:

www.umlib.nl/taverne-license

Take down policy

If you believe that this document breaches copyright please contact us at:

repository@maastrichtuniversity.nl

providing details and we will investigate your claim.
}

Copyright and moral rights for the publications made accessible in the public portal are retained by the authors and/or other copyright owners and it is a condition of accessing publications that users recognise and abide by the legal requirements associated with these

- Users may download and print one copy of any publication from the public portal for the purpose of private study or research.

- You may not further distribute the material or use it for any profit-making activity or commercial gain

If the publication is distributed under the terms of Article $25 \mathrm{fa}$ of the Dutch Copyright Act, indicated by the "Taverne" license above, 


\section{At a critical juncture? Change and continuity in the institutional development of the council secretariat}

\section{Thomas Christiansen \& Sophie Vanhoonacker}

To cite this article: Thomas Christiansen \& Sophie Vanhoonacker (2008) At a critical juncture? Change and continuity in the institutional development of the council secretariat, West European Politics, 31:4, 751-770, DOI: 10.1080/01402380801906015

To link to this article: https://doi.org/10.1080/01402380801906015

曲 Published online: 19 Jun 2008.

Submit your article to this journal $๘$

Џ Article views: 798

Q View related articles ¿

4 Citing articles: 4 View citing articles 단 


\title{
At a Critical Juncture? Change and Continuity in the Institutional Development of the Council Secretariat
}

\author{
THOMAS CHRISTIANSEN and SOPHIE VANHOONACKER
}

This article provides a historical institutionalist perspective on the General Secretariat of the Council of Ministers - an institution that has expanded significantly over the course of the integration process and whose role in the institutional politics of the EU has been recognised as significant in the recent literature on the subject. Charting the history of the institution, we demonstrate the way in which the original institutional design contributed to a particular trajectory which can be understood as a "pathdependent' development. However, we also identify recent developments which can be seen as a break with the historical legacy of the Secretariat - an observation which raises the question as to whether the institution is at a critical juncture in its development. The article closes with an examination of the present and future challenges the Council Secretariat is facing at this time.

This article examines the historical trajectory and current challenges of a European institution that has remained under-researched: the General Secretariat of the Council of Ministers of the European Union. For most of the history of the integration process such a lack of attention might have been justified because of the limited role that the Council Secretariat appeared to play in EU politics. Recently, however, research on a number of issues - the management of EU foreign policy and the conduct of EU treaty reform - has demonstrated the contribution that this body makes to EU decision-making. We therefore believe that there is a strong case for developing a better understanding of the Council Secretariat.

The role of the institution ${ }^{1}$ has changed over time, and it has expanded significantly in recent years - we will discuss the details of this expansion of tasks in detail below. What there has not been, however, is a formal reform of the institution, either recently or indeed at any point in its history.

Correspondence Address: t.christiansen@eipa-nl.com; s.vanhoonacker@politics.unimaas.nl 
Instead, the Council Secretariat has evolved gradually, in line with the changes that have occurred within the Council of Ministers (of which it forms a part) and of the wider changes which the Union has undergone. This presents the puzzle of an institutional development that only partially mirrors the shifting politics of the environment: there are institutional changes which need to be explained, but there is also a pattern of continuity which needs to be studied. It is against this background of seeking to account for both institutional change and continuity that we have chosen to approach the study of the Council Secretariat from the perspective of historical institutionalism.

Historical institutionalism seeks to explain institutional choices by examining the development of the institution over time. One of the key concepts that historical institutionalism employs towards this purpose is that of path dependency - the identification of a particular trajectory of the institutional development that has been formed through the historical continuity arising from past decisions. Such an approach allows us to gauge the relationship between continuity and change and to make statements about the reasons for both inertia and responsiveness of the institution in relation to the macro-social context within which it operates. The macrosocial context here is the overall institutional evolution of the Union of which the Council Secretariat has been a part. Institutional arrangements, in this perspective, are the result of a 'logic of appropriateness' rather than the 'logic of consequences' posited by rational approaches (March and Olsen 1989).

The aims in this article are therefore threefold: first, we assess the nature of the previous path of institutional development in order to be able to make statements about the logic according to which this development has occurred; second, we examine the impact of the more recent developments to see whether these changes do indeed represent a significant change from the historical legacy of the institution - a development that could be classified as a 'critical juncture' in terms of the historical institutionalist perspective. Finally, building on this analysis of both long-term and recent developments, we briefly discuss the future challenges that the Council Secretariat is facing.

In order to address these concerns, the article proceeds as follows: the next section introduces the historical institutionalist approach, discussing the way in which this approach can add value to the study of the Council Secretariat. The subsequent section charts in some detail the historical evolution of this institution, a discussion that in turn provides the foundation for the following assessment of the way in which recent developments - in particular the rapid expansion of the foreign and defence policy role taken up by the Secretariat and the changes imposed on the institution through the Eastern enlargement of the Union - have, or have not, diverted the Secretariat from its traditional path of institutional development. The article concludes with a discussion of the future challenges that the findings presented here imply for the Secretariat. 


\section{A Historical Institutionalist Perspective on the Council Secretariat}

Approaching the study of the Council Secretariat from a neo-institutionalist perspective means to start from the basic assumption that institutions matter'. The question is, of course, how they matter and in which way they have influenced decisions. This has been the subject of some debate and a number of different 'institutionalisms' have been advanced in order to provide answers to these questions (Hall and Taylor 1996). One of these, historical institutionalism, emphasises the temporal dimension in the search for an explanation about institutional choices (Hinnfors 1999; Pierson and Skocpol 2000; Blyth 2003). While there have been debates about the utility of historical institutionalism (Kay 2005), we believe that this approach is valuable in the analysis of the evolution of an institution such as the Council Secretariat that is part of the larger institutional development that the process of European integration constitutes.

Historical institutionalism is regarded as useful in this context because it seeks to provide an explanation not only of institutional change, but also of continuity. As we have argued above, and as we will demonstrate in more detail below, there is strong evidence to suggest that the Council Secretariat, as a sub-system of the broader institutional structure of the European Union, remained remarkably resilient to change over a long period of its history. In other words, the institutional parameters of the Council Secretariat did not necessarily change in line with the massive shifts that the Union underwent throughout its history. Instead, we appear to have witnessed a more gradual process of adaptation which allowed the Council Secretariat to remain fairly constant. It is against this historical background that recent developments, implying more substantial changes to the institution, need to be examined.

Historical institutionalism as an approach is well-equipped to confront the puzzle of institutional stability and change. It makes a number of assumptions, however, that have to be spelt out clearly in advance. The first set of assumptions concerns the interaction between structures and agency. Unlike other approaches that give priority, whether explicitly or implicitly, to one ontology or another, a historical institutionalist approach recognises both structures and actors to be mutually constituted. Actors are to some extent defined by their role in the broader structures within which they work and act, and even though their behaviour is not determined by these structures, their interests and their identity are shaped by them. At the same time, structures, and this includes both legal-institutional and ideational structures, cannot be seen as determining actors' behaviour, and even less so decisional outcomes, but instead are themselves subject to change under the behaviour of actors (Hall and Taylor 1996, 1998; Hay and Wincott 1998). Denying both actors and structures ontological priority, but instead regarding both as mutually constitutive of one another, is what requires us to look at the process of interaction. Only over time can it be fully 
understood how the interaction between structures and agency, and between interests, ideas and identities, pans out. It is on the basis of such a procedural approach that we can then make statements that provide an explanation of institutional evolution.

This recognition of the role of both actors and structures in the explanation of institutional developments is particularly pertinent in the case of the Council Secretariat. Here we have an institution which provides those working within it with a structure - a set of formal-legal rules as well as socio-cultural norms - but which at the same time is also an agent in the wider politics of the European Union. 'institutions...can shape and constrain political strategies..., but they are themselves also the outcome (conscious or unintended) of deliberate political strategies of political conflict and of choice' (Thelen and Steinmo 1992: 10) - this tenet of institutional analysis accurately sums up the situation concerning the Council Secretariat.

It is against this background that we can specify in more detail the nature of a historical institutionalist approach to the study of the Council Secretariat. The concept of path-dependency is crucially important in this context. Path-dependency emphasises the stickiness of prior institutional choices for subsequent institutional development. In brief, a previous decision to set up a decision-making environment in a particular way has a tendency to reproduce itself through a sequence of events which follow from the original institutional choices (Collier and Collier 1991). It is due to such stickiness of institutional choices and the inertia of bureaucratic processes that institutions evolve along a certain path - one that is foreshadowed by the original design and resilient to the kind of changes that the environment may experience. And it is precisely the observation of this process over time - the temporality of a historical institutionalist approach - that permits us to study whether, and how, such a dynamic has been unfolding.

At the same time, historical institutionalism is not blind to the possibility of change. However, from such a perspective one would expect for change to occur only under extraordinary circumstances, when changes in the external environment, for example in the preferences of the actors or in the macrosocial context, are so significant that these overcome the stickiness of existing institutional arrangements. It is during such a critical juncture that we then witness institutional change and indeed periods of institutional instability, which ultimately establish a different development path for the institution (Thelen 1999). What constitutes such a critical juncture may be difficult to define in advance, but it can be seen as having occurred if the new or changing institutional development points in a direction marking a departure from the existing developmental path.

We also include in our approach an awareness of the ideas, values and norms that form part of the institutional culture and that contribute to the direction of the institutional environment. Recognition of the role of ideas and norms can also be regarded as being part of a historical institutionalist 
approach (Hinnfors 1999; Pierson and Skocpol 2000; Blyth 2003), but can also be seen as constituting the core of a separate, sociological institutionalist approach (Hall and Taylor 1996; Lewis 2006). This sensitivity to (unwritten) cultural norms and values is a key part of the sociological dimension of institutional analysis (Rosamond 2000). Ideas matter in this respect as part of a cognitive map that is being developed in an institution - a 'theory of the institution' about itself which then has consequences for the actions of individual actors (Jachtenfuchs 1997). In the case of the Council Secretariat, there are powerful self-referential concepts at work - the idea of being an 'honest broker' being one of them - that may heavily influence the way in which the institution and those working within it operate (Tallberg 2006: 45).

Rationalist, sociological and historical varieties of institutionalist analysis have recently been applied to the study of the Council Secretariat (Beach 2004; Hamlet 2006; Lewis 2006) - a trend that is an expression of the much wider debate about the different kinds of new institutionalism that have been advanced. We do not have the space here to go into this more general debate. Instead, it will be evident from what has been said above that we are opting for the historical and sociological rather than the rationalist variant of the neo-institutionalist approach.

The key element of such a historical and sociological institutionalist approach is the temporal tracking of institutional developments, identifying the way in which specific (and contingent) choices at the outset lead to a pathdependent trajectory, as well as a sensitivity to the occurrence of critical junctures. Looking towards a detailed analysis of the Council Secretariat, this implies an in-depth examination of the history of the institution, pinpointing those elements in the evolutionary path that have contributed to institutional stability and continuity. The subsequent section will provide this survey of the history of the institution. Based on the insights gathered in this way, we will then move on to answering some of the key questions that historical institutionalism poses. First, what have been the driving forces in the institutional development of the Council Secretariat? Second, to what extent have the changes in the macro-social context contributed to institutional stability and change? Third, what has been the effect of the ideas, values and norms that have been cultivated inside the institution? And, finally, what is the effect of the more recent developments in the European Union for the future evolution of the Council Secretariat?

\section{The Establishment and Growth of the Council Secretariat}

In examining the historical development of the Council Secretariat through the lens of the historical institutionalist approach, one may distinguish between three periods: first, the actual setting up of the institution in the foundation years of the integration process. It is during this period that key choices were made which - if the thesis of a path-dependent trajectory is 
correct - would result in subsequent events already foreshadowed by the initial institutional design. Second, a period of stability and growth during which the Secretariat also underwent significant changes, albeit without any formal reform of the institution. And, third, there is the more recent period which has been one of considerable turbulence, raising the question of whether the established developmental path is sustainable or whether, by contrast, the Secretariat is facing a critical juncture in its institutional life.

\section{Institutionalisation}

In order to account for the origins of the Council Secretariat one needs to go back to the very early period of European integration. The creation of a 'Secretariat' was one of the first decisions of the inaugural meeting of the Council of Ministers of the European Coal and Steel Community (ECSC) meeting in Luxembourg in September 1952. The provisional rules of procedure adopted on that occasion barely spent one line on this new body and defined its role as purely supportive: to assist the Council under the responsibility and guidance of the Presidency (Règlement interieur provisoire). Originally the small Secretariat was based in Luxembourg. With the creation of the EEC and Euratom, its Secretary General, the Luxembourg diplomat Christian Calmes moved to Brussels to take over leadership of the Secretariat General of the European Communities. Until the merger Treaty of 1967, however, a small ECSC section was maintained in Luxembourg (Mangenot 2002; 2003a and b).

What needs to be noted in this context is the 'thinness' of the formal rules on which this institutional development was based. The Council Secretariat is not mentioned in the founding treaties (it was only introduced formally with the Maastricht Treaty). The Secretariat was however referred to in the Council's own Rules of Procedure (RoP), and changes to these internal RoP reflect the significance the Secretariat has had for the operation of the Council from the inception of the Communities. But even here references to the Secretariat were rather brief and cursory. Essentially, an institution was initially set up without clear formal rules governing its activities, and therefore the foundation was laid for unwritten rules, existing practices and bureaucratic reflexes to fill the normative vacuum. ${ }^{2}$

Against this backdrop, the Secretariat, interacting with other players such as COREPER, the Presidency, the High Authority and European Commission, explored its scope of manoeuvre and gradually the office took shape. In the early years it fulfilled primarily an organisational and administrative function. It was in charge of organising meetings, preparing agendas, translating and distributing documents, drafting minutes. Its main task was to create the conditions for a smooth running of the Council machinery (Hayes-Renshaw and Wallace 2006; Sherrington 2000; Westlake and Galloway 2004). This may be a low-profile job, but it was crucial for the efficiency of the day-to-day policy-making process. 


\section{Institutional Growth, Stability and Change}

With the gradual extension of Community competencies, the first enlargement (1973) and the proliferation of meetings at various levels, the Secretariat's workload steadily increased. These new developments led to the creation of new Directorates-General and an increase in the number of staff (Mangenot 2002). By 1975, the number of A officials had grown from 5 (1953) to 161 and the total number of staff had expanded from 30 to $1,475 .^{3}$

At the same time, there was a gradual evolution and expansion of the Secretariat's administrative function. Due to the regular rotation of the Presidency, ${ }^{4}$ the Secretariat developed into the Council's institutional memory and also functioned as a bridge between various chairs. Its officials not only supported the Council in all its formations but also its preparatory bodies such as the Committee of Permanent Representatives (Coreper) and the working groups. As a result, the Secretariat also became a source of coordination, coherence and continuity in the Council's work. The Council decision of 1980, appointing the third Secretary General, explicitly referred to these tasks (Decision 80/918/EEC).

From the late 1960s onwards, we see the gradual development of an entirely new function which consists in helping the chair with the formulation of compromises. Following the 'empty chair crisis' (1965-66), the European Commission's position as a broker came under pressure and the Presidency gained more leverage in fulfilling this task (Kirchner 1992). As the Council Secretariat follows dossiers throughout the legislative process, it is well informed about the various national positions and well placed to advise the chair in forging deals. Also its legal and procedural expertise are key when advising the chair in possible compromise solutions, and increasingly the Presidency came to rely on the Secretariat for the drafting of text proposals or the provision of tactical advise. This did not imply, however, that the Secretariat could articulate its own position. The norm has been that its civil servants are impartial. They are expected to look for the common interest and facilitate the problem-solving process. As one senior official of the Council Secretariat remarked, 'I don't mind whether they decide to paint the room black or white, as long as the decision is taken in the correct way' (quoted in Schout and Vanhoonacker 2006: 1054). Whether there is scope for this brokering function, however, is contingent entirely upon whether the Presidency is willing to take its suggestions on board. As has been argued elsewhere, due to their limited resources, smaller member states tend to rely more on the work of Secretariat staff than larger ones (Christiansen 2002; Elgström 2003; Schout and Vanhoonacker 2003; Tallberg 2003).

A further development which strengthened the position of the Secretariat was the creation of the European Council (1974). In addition to being involved in the organisation and provision of secretarial services, the Secretariat, from 1982 onwards, started to play a key role in the preparation 
of the draft Presidency conclusions (Bulmer and Wessels 1987; Werts 1992; Mangenot 2002; Council 2006). ${ }^{5}$ Its long-term experience with European negotiations implied that it was well placed to formulate a text supported by the large majority of the delegations. As a result of this role at the highest political level, the position of the Secretary General grew in importance, and the prestige of the function also reflected on his institution. Niels Ersbøll, former Permanent Representative of Denmark to the EC and Secretary General from 1980 to 1994, played a key role in giving shape to this new role. Coming from a small member state and extremely knowledgeable about EC affairs, he enjoyed the trust of the member states and managed to build up a central position in advising succeeding Presidencies in forging compromises. Another effect of the Secretariat's role in preparing European Councils was the establishment of direct contacts with the President of the European Commission (Mangenot 2002). ${ }^{6}$

In the 1990s, the Secretariat again received an important boost, not so much because it was given formal recognition in the Treaty on European Union (Art. 151, para. 2), ${ }^{7}$ but mainly as a result of developments on the international and European scene. The fall of the Berlin wall opened the prospect of Eastern enlargement and simultaneously raised the need for a further deepening of European integration and the adaptation of its institutional framework. Through a series of IGCs (Maastricht, 1991; Amsterdam, 1996-97; Nice, 2000; Constitutional Treaty, 2003-04), the member states tried to strengthen the European construction by expanding its scope to new areas, by reinforcing the role of the European Parliament, and by reforming its institutional underpinnings and the decision-making process.

From the 1990s, the continuous process of treaty reform - which can also be seen as a process of the constitutionalisation of the European Union - created new opportunities for the Council Secretariat (Deloche-Gaudez 1994; Christiansen and Reh forthcoming). A small group of highly qualified officials, who mostly remained the same throughout the various IGCs, assisted the Presidency as the 'conference secretariat' with the taking of minutes, drafting of texts and the formulation of compromise proposals (Galloway 2001). Furthermore, the Secretariat also served as the IGC's legal service. In contrast to the SEA negotiations, where it shared this responsibility with the legal service of the Commission, the Council Secretariat now had the sole responsibility for this influential function (Christiansen 2001). Its procedural and legal expertise, its informational advantages and brokering capacities gave the Secretariat scope to play an active role in defining negotiation strategies, drafting treaty amendments and elaborating compromises (Beach 2005). But, as in the legislative process, the Secretariat's role was only as strong as the Presidency allowed it to be (Beach 2004, 2006).

Furthermore, the Secretariat was also affected by the changing institutional balance after Maastricht. With the introduction of the co-decision procedure, the Council and the EP became co-legislators, and had a shared 
interest to reach an agreement on legislation (Shackleton 2006). The increased institutional interaction intensified the Secretariat's contacts with the EP. As most dossiers span more than one Presidency, the Secretariat fulfilled an important bridging function, providing an element of continuity between the rotating chairs. In contrast to the country at the helm, its civil servants are well versed in this complex decision-making procedure and its many informal 'do's and don'ts'. The chair is assisted by the responsible Directorate General as well as by a special co-decision unit known as the 'dorsale' or 'backbone'. The officials in the dorsale follow all legislative acts falling under the co-decision procedure and closely cooperate with their counterparts in the EP and the Commission.

With the entry into force of the Treaty on European Union, the Secretariat also started to play a role in the Treaty's newly established intergovernmental pillars of the Common Foreign and Security Policy (CFSP) and Justice and Home Affairs (JHA). Since the Single European Act (1987), there had been a small but independent secretariat for European Political Cooperation (EPC), the predecessor of CFSP (Sanchez da Costa Pereira 1988; Nuttall 1992). The 16 EPC staff members (6 diplomats and 10 secretaries) were based in the same building as the Council Secretariat, but were seconded and paid by their national ministries. They formed a separate entity with its own rules and internal codes. To emphasise its distinct intergovernmental character, the EPC unit was only accessible through a special combination lock (Nuttall 2000). With Maastricht the EPC secretariat was merged with the Council Secretariat and the Directorate General for External Relations (DG E) was reorganised into two directorates, one for external economic relations and one for CFSP. The latter was manned with a mixture of diplomats delegated from the national capitals (one per member state), civil servants of the Council Secretariat (11) and the Commission (1) (Nuttall 2000). The decision to work with seconded officials can be explained by the member states' reluctance to give up sovereignty in the sensitive area of foreign policy. In practice the links between Brussels and the national capitals were further strengthened.

In the new policy areas of CFSP and JHA, the rules of the game were not those of the supranational Community method, but of intergovernmental cooperation. Decisions were taken by unanimity, and policy formulation and implementation fell under the responsibility of the member states and the Presidency instead of the European Commission. Initially the role of the Council Secretariat was similar to that in other policy areas: supporting the chair and the Council with the organisation of meetings and the management of the negotiation process. This changed radically, however, when the European Council of Cologne in June 1999 decided to establish a European Security and Defence Policy (ESDP) and appointed Javier Solana as High Representative for CFSP and Secretary General of the Council Secretariat (Howarth 2001). Spurred by the poor EU performance in the Balkans, the member states agreed that the time had come to engage in a more 
operational foreign policy. They expressed the ambition to carry out the full range of Petersberg tasks as defined in the Treaty on European Union (TEU): humanitarian and rescue tasks, peace-keeping tasks and tasks of combat forces in crisis management, including peace-making. As a result, the Secretariat for the first time in its history was also entrusted with executive tasks.

\section{Recent Developments: Towards a 'New Secretariat'?}

The twin decisions of the Cologne European Summit in 1999 - establishing the ESDP and appointing Javier Solana as High Representative constituted a watershed in the development of the Council Secretariat. By nominating a former Secretary General of NATO (1995-99) and former Spanish Minister of Foreign Affairs (1992-95), the office of SecretaryGeneral was no longer headed by a top-level official or diplomat, but by a high-profile politician. Entrusted with the broad task of assisting the Presidency with the formulation, preparation and implementation of CFSP (Art. 26, TEU), Solana decided to concentrate fully on his foreign policy mission and left the day-to-day management of the Secretariat to the Deputy Secretary General Pierre de Boissieu. The vague formulation of his mandate provided him with sufficient latitude to strongly influence the shape and content of his new function. At the same time, the important internal responsibilities of the Deputy Secretary-General were recognised in the Treaty (Art. 207, TEU) and enhanced in the Council's internal RoP.

These developments had important implications for the administrative level of the Secretariat, in terms of its organisational structure, staff and responsibilities. In the monitoring and analysis of international developments, Solana was assisted by a newly created 'Policy and Early Warning Unit', better known as the Policy Unit. It fulfilled an early warning function in case of potential crises, and its staff could, in contrast to the rest of the Secretariat, take the floor in CFSP meetings. Apart from a small number of civil servants from the European Commission, the Council Secretariat and the WEU Secretariat, the unit was primarily staffed with seconded national diplomats. The analytical and strategic task of the policy unit was kept separate from the supportive task of DG E. In practice, this artificial distinction never worked, and from 2004 onwards members of the policy unit have been increasingly integrated in the respective geographical units of DG E (Duke and Vanhoonacker 2006).

DG $\mathrm{E}$ itself has been expanded with two new directorates, respectively dealing with defence questions (directorate 8) and with civilian crisis management and coordination (directorate 9 ). They are both predominantly staffed with seconded experts and diplomats. Furthermore, the Secretariat has also become the home of the EU Military Staff and the situation centre (SITCEN). Both fall directly under the authority of Solana. While the former plays a central role in early warning, situation assessment and strategic 
planning of operations, the intelligence officers of SITCEN analyse intelligence material and monitor potential crisis situations. For certain issues such as non-proliferation of weapons of mass destruction and human rights, Solana can rely on Personal Representatives. They play a coordinating role and assist him with the implementation of policy decisions.

The staff working in the area of CFSP and ESDP are divided from the rest of the Secretariat in two ways: through the strong presence in their ranks of seconded diplomats and experts, and through their role in the process of policy formulation and implementation. Formally the High Representative has no right of initiative, but by launching policy papers and bringing problem areas to attention, he can influence the agenda and steer the debates in a certain direction. The staff of the policy unit provide him with the background documents required to fulfil this agenda-setting function. Furthermore, the Secretariat also plays a role in the preparation and implementation of civilian and military missions. It draws up background documents and draft joint actions. Once the member states have agreed upon the launching of a civilian or military operation, it prepares an operational plan, in cooperation with the Commission and the Presidency. Also during missions it fulfils certain implementing tasks. Through the socalled Athena mechanism, for instance, it administers the financing of the common costs of military operations (Missiroli 2003).

The presence of men and women in uniform on the premises of the Secretariat and their close cooperation with NATO have also raised new challenges with regard to the security and protection of confidential information. The Justius Lipsius building failed the security test, and all ESDP-related departments are housed in a separate building in the Avenue de Cortenberg. This is not conducive to coordination with other departments dealing with external relations, but it symbolises very well the differences between the two worlds in which the officials from the Secretariat operate. The staff working in the first pillar still primarily fulfil the traditional administrative and advisory role, while those in the second pillar increasingly combine this with executive responsibilities. While the former group consists of civil servants who passed the concours, the second group is heavily dominated by seconded experts and diplomats. This is not only due to a lack of expertise in the Secretariat, but can also be explained by the desire of the national capitals to maintain direct control over this sensitive policy area. In 2007, the group of seconded staff numbered approximately 210 (25 in the policy unit, 165 military, and 20 police officers). In total they represented up to 28 per cent of the policy-making staff in the Secretariat. ${ }^{8}$

Although this intergovernmental approach is attractive for member states reluctant to pool sovereignty, it undeniably presents a number of pitfalls (Vanhoonacker and Dijkstra 2006). First, one can question whether the Secretariat is equipped to deal with its executive function. Traditionally, Council civil servants have been trained to provide logistic support and to assist the chair in managing the negotiation process. Most of them do not 
have a diplomatic background, and contrary to national foreign ministries, the Secretariat cannot look back on a long foreign policy tradition. Bringing in national expertise by seconding diplomats addresses this problem, but it also has drawbacks. More than 50 years of socialisation means that the Secretariat has developed its own administrative culture. Its staff adheres to well-established professional norms such as efficiency and impartiality and has internalised rules of appropriateness. National diplomats may not necessarily share or be aware of their way of thinking. Although research on the Commission has illustrated that delegated national civil servants are not immune to their new international environment, the process of adaptation takes time and can be the cause of tensions (Egeberg 2006; Trondal 2006). At this moment there is hardly any empirical data about the interaction between the Secretariat's traditional civil servants and the seconded staff. It is well known, however, that when in the early 1990s the CFSP unit was staffed with a mixture of seconded and Secretariat officials, the process of integration took time and was not without problems (Dinan 1999; Nuttall 2000).

The question of expertise is closely linked to that of access to information. The secondment of national diplomats in the Secretariat and the establishment of a Joint Situation Centre staffed with intelligence officers have considerably increased the information flow between Brussels and the national capitals. It remains the case, however, that the Secretariat, in contrast to the Commission, has no delegations in third countries. Whether or not the Secretariat is properly informed depends to a large extent on the goodwill of the member states and the European Commission.

Finally, the Secretariat's new executive role also demands improved coordination mechanisms, both internally as well as with the European Commission. The latter can look back on a long tradition of fulfilling executive tasks in the field of trade and development. It was not amused by the Secretariat's interference in the field of external relations and initially this led to bureaucratic turf battles (Spence 2006). This institutional rivalry was further fuelled by the fact that there are many grey zones and that foreign policy projects do not necessarily respect the demarcation between pillars. Gradually, however, both players have been able to find a modus vivendi, and modalities for cooperation and coordination have developed (Council 2003; Vanhoonacker forthcoming; EU crisis response capability revisited).

\section{A Path-Dependent Development? Assessing the Historical Evolution of the Council Secretariat}

Having reviewed the historical evolution of the Council Secretariat, we can now engage the questions raised previously. The first task in this respect is to identify the historical legacy that was created at the outset. A number of key factors can be identified in this regard - key factors which were contingent at 
the time (other choices would have been possible then), but which subsequently contributed to the institutional development that we have seen. These factors were, first, the creation of a small administration that would work with and under the supervision of the member states, in institutional opposition to the European Commission; second, the decision to give significant responsibilities to a rotating Presidency which is being assisted by the Secretariat; and, third, the decision to leave the work and the internal organisation of the Secretariat fairly unregulated for the first few decades of its institutional life.

The combined effect of these initial choices for the design of the institution was to steer it towards a particular kind of development. For example, having the role of 'assisting' the Presidency meant that the institution had to grow into a body that institutionalised permanency and whose staff would work in the 'shadows' rather than in the political spotlight, thus emphasising the supporting role and the impartiality of the Council Secretariat (Beach 2004; Christiansen 2002).

Working close to national civil services and being occupied largely with the legal aspects of the Community's legislative programme implied the import of a bureaucratic and legalistic culture into the staff of the Council Secretariat - which in turn became the source of the norms and ideational structures of the institution's staff. This pattern of the development of a normative foundation for the work of the Secretariat based on the professional standards of its staff was also the result of the under-specified formal underpinnings of this institution that we have observed. Finally, this original set-up also implied that with future enlargements the role of the institution would expand: a greater number of member states requires more resources spent on coordination, and new member states holding the rotating Presidency mean more scope for the expertise of the permanent Secretariat (Juncos and Pomorska 2007).

These observations demonstrate that the initial design of the institution had far-reaching consequences throughout its history. The increasing reliance of countries holding the Presidency, the gradual growth of the institution to reflect the expansion of competences and rising number of member states, and establishment of a certain esprit des corps among the staff of the Secretariat - these developments which are the hallmarks of the institutional life of the Secretariat all had their origin in the choices that were made at the outset of the institution. Institutional changes that happened to the Council Secretariat did not require any formal institutional reforms precisely because such changes inevitably followed from the choices that had been made initially.

This observation leads to the recognition that, beyond concrete legal and procedural choices that have had an indirect impact on the evolution of the Council Secretariat, we need to recognise the power of ideas that have helped to shape the institutional development of the Union. Here it may be worth pointing to the discourse about impartiality, the protection of 
diversity, the representation of national interests and the idea of 'intergovernmentalism' as a way of achieving both national protection and member state consensus. It has been on the basis of these discourses that the Council Secretariat has been receiving additional tasks and responsibilities, as it has been regarded as the institution that is more 'intergovernmental' than the Commission. Such a development demonstrates the effects of a 'logic of appropriateness', even if it contributed - ironically - to making the Council Secretariat more of a supranational institution.

The institutional evolution of the Council Secretariat can be linked to these initial choices and subsequent developments in the overall context of European governance. However, in addition to these external factors we also need to recognise the internal dynamics of the Council Secretariat itself. On the one hand, there has been the institutional self-interest to protect the institution, inter alia by expanding its role and establishing it as a key part of the EU's administrative system. Such institutional self-interest can operate in a number of ways, but in this context it might be important to point out that, as mentioned above, senior officials participated in the IGC secretariats at the Maastricht, Amsterdam and Nice Treaty negotiations, and that the subsequent expansion of Council Secretariat responsibilities might be linked to the involvement of senior officials from the institution in the IGCs through their work in the conference secretariat and/or the Council's legal service.

However, identifying such a path-dependent development should not imply that revolutionary changes might not occur. Radical changes to the institution would need to be seen as a critical juncture where a number of important factors imply a departure from the previous path. Our tracing of the history of the Council Secretariat, and, in particular, the identification of a number of important developments in the recent phase of integration, raises the question as to whether we are witnessing such a critical juncture now.

As we have seen in recent years, successive mergers and addition of new tasks have produced a dual administration within the Secretariat. The identity of the 'old' Secretariat is now under threat from the distinct approach of those in the 'new' Secretariat - the foreign policy and military machinery, which is concerned not with the quiet work in support of legislative procedures, but with the executive management of foreign and security policy. This requires more rapid reactions to changing circumstances, direct action by Council Secretariat staff and thus a public profile to the role of the institution that is totally alien to the 'old' Secretariat. The result of the presence of such differing, even conflicting, cultures within the institution is internal tension and potential fragmentation.

If this is a concern, then the impact of enlargement must also be considered. The arrival of new staff from the new member states, the growing size of the institution overall and the ensuing changes to the organisational structure have all combined to create the potential to unsettle 
the traditional beliefs and norms that have helped to maintain continuity in the Secretariat's institutional development. So far, the 2004 enlargement has left a strong mark on the internal processes of the Council Secretariat. ${ }^{9}$ In this respect the Secretariat mirrors the developments elsewhere in the institutional architecture of the EU - generally the images of 'gridlock' or 'blockage' that accompanied accounts of the workings of the EU if Eastern enlargement was to occur without fundamental reforms have not been borne out (Best et al. 2008). There have, for example, been fewer promotions to senior positions of Secretariat officials from the new member states compared to the appointments in the European Commission, and the administration has resisted the imposition of the kind of quotas for new appointments from the new member states that were introduced in the Commission. However, further pressure for internal changes is to be anticipated given future enlargements and the need for geographical balance among senior levels within the administration.

Institutional cohesion, which for decades had been sustained by a common set of beliefs and norms about the role that the institution should be playing in the Union, is therefore under threat from a number of directions: the arrival of new kinds of professional logics (diplomats and military personnel) working alongside the older community of lawyers as well as the arrival of new staff as a result of enlargement. While the strains are already showing, the institution has so far managed to preserve an image of internal cohesion. The question is whether, or indeed for how long, such an image can be maintained if the internal tensions become greater and ideational cohesion is more seriously at risk. In this respect, the issuing of a 'mission statement' espousing the 'core values' of the Secretariat staff is a very interesting development (Council 2007). This brief, one-page document states that professionalism, impartiality and esprit de corps are the core values to which officials in the Secretariat adhere. These are indeed the values that we have also seen at work in the self-perception of the Secretariat throughout the decades, and as such this announcement does not appear as a break with tradition. However, the very fact that such a public statement was deemed to be necessary, implying that pure reliance on the longestablished unwritten norms is apparently not sufficient any more, is a sign that the internal cohesion of the institution might be in doubt.

In sum, there have been significant changes to the way in which the EU has made its policies since the 1950s, but the adaptation of the Council Secretariat has not followed a clear path of rational decisions about this process; rather its path has been determined by gradual adaptation, unintended consequences and internal processes within the Council Secretariat itself. As such, the institutional development of the Council shows 'historical causes' rather than 'constant causes' at work (Collier and Collier 1991). These explanatory factors might be more difficult to identify when taking only a brief look at the current situation, but they quickly become evident as part of the temporal study that we have undertaken here. 
In this context we have identified the period around 1999, and the Cologne European Council in particular, as a decisive moment in terms of a possible shift of the institutional development. Given the very different logics that have entered the Council Secretariat since then, this may indeed be seen as the kind of critical juncture that historical institutionalism regards as the point at which there is a departure from the previous pathdependent sequence of events. The changes taking place in the Secretariat can only be explained against the background of the changing European and international context. The collapse of the bipolar structure and uncertainty about the future of the transatlantic relationship gave an important impetus to the development of an independent European security identity and opened the door for eastern enlargement. Without this shock in the external environment, the 1999 developments in the Secretariat would not have taken place. At the same time, the preferences of the member states have also played an important role. It may have been more efficient to entrust the implementation of ESDP to the European Commission, but for most national capitals this was a bridge too far. In an attempt to maintain control over the sensitive foreign policy area, they opted for the expansion of the role of the Council Secretariat, a body over which national governments were considered to have a stronger influence. The lack of prior expertise was compensated by the delegation of national diplomats, a further device to keep a firm grip on ESDP's Brussels-based players. The Secretariat's own role in fostering the changes is negligible. Although it had gradually started to assume a modest foreign policy role since the Single European Act, it had always been a player at the service of the member states and, contrary to the European Commission, it did not have a voice of its own.

\section{Conclusion}

Our study underlines a number of points. First, path-dependency is there, but it only demonstrates the continuity of the work of the Council Secretariat in the absence of formal changes to the institution. Adaptation to changing circumstances occurs in a more informal manner, through gradual institutional changes and as unintended consequences of broader institutional developments, not as the result of strategic decisions to establish a particular institutional design.

Second, the nature of these unintended consequences is such that, over time, the institution may develop pathologies that reduce internal cohesion and effectiveness significantly. Cultural norms and common values that have been developed within the administration may clash with countervailing ideas as fragmentation occurs and internal tensions increase. The development of a dual administration since the late 1990s - traditional policymaking and legislative bureaucracy on the one hand, emerging diplomatic and military components on the other - may be an example of that. 
Third, the changes the Council Secretariat has undergone since 1999 creation of the post of HR, establishment of the EU military staff, arrival of the new member states - may in this respect come to be seen as a critical juncture that forces the Council Secretariat onto a different development path towards a much more politicised executive agency, from the established role of providing a more subtle influence in the legislative process. The additional tasks acquired in this period go hand-in-hand with a new set of ideas and norms that has entered the institution as a result of these changes.

The creation of the post of a High Representative of the Union for Foreign Affairs and Security Policy and the establishment of a European External Action Service (EEAS) under the Lisbon Treaty may be decisive in determining whether the early phase of the twenty-first century will turn out to have been a critical juncture for the evolution of the Council Secretariat. Should these changes be implemented, the 'outsourcing' of foreign policymaking and crisis management to such an external action service may go some way towards putting the 'old' Secretariat back on its established path. The crucial issue then will be the nature of the relationship between this EEAS, the European Commission and the High Representative, but presumably it will be outside the institutional logics of the Council Secretariat. This would be a significant change from the existing path of institutional development, but as such it would be a way to alleviate the tensions between the 'old' and 'new' parts of the Secretariat that we have explored in this article.

\section{Acknowledgements}

We are grateful for the useful comments we received from the conference participants as well as from the editors of this special issue, and we acknowledge the valuable research assistance provided by Johanna Oettel. The usual disclaimer applies.

\section{Notes}

1. While the Council Secretariat is not an official EU institution in the formal understanding of the treaties, it is treated here as an institution for the purposes of analysis.

2. A detailed analysis of the evolution of the Council's own rules of procedure demonstrates that these have developed in response to the changing external circumstances and reflect the growing importance of the Secretariat. Apart from a series of minor changes throughout history, there were six major revisions of the RoP which resulted in new versions being published in the Official Journal. This occurred in 1979, 1993, 1999, 2000, 2002, 2004 and 2006 - a development that reflects the increasing and accelerating juridification of the Council's work in the wake of successive treaty changes and enlargements. If the early period of the Secretariat's institutional life was fairly unregulated - the RoP foreseen by Art.5 of the Merger Treaty in 1965 were only adopted in 1979 - it allowed (or required) a process of institutionalisation along the lines of other, unwritten norms.

3. Growth in the total number of staff: 30 (1953); 264 (1959); 603 (1970); 1,475 (1975). Growth in the number of A officials: 5 (1953); 68 (1959); 94 (1970); 161 (1975) (Mangenot 2002). 
4. In the ECSC the Presidency rotated every three months; in the EEC and Euratom there was a six-month rotation.

5. Before, it was the Permanent Representatives who prepared the draft conclusions.

6. Before, the contacts with the Commission only went through the Secretariat General of the Commission.

7. Art. 151, para. 2, TEU stipulates, 'The Council shall be assisted by a General Secretariat, under the direction of a Secretary-General. The Secretary-General shall be appointed by the Council acting unanimously. The Council shall decide on the organization of the General Secretariat.'

8. The total number of Secretariat officials involved in policy-making numbers 750 (this figure excludes secretarial staff and linguists) but includes military and police officers. There are 540 permanent AD officials; 140 of them (25 per cent) work for DG E.

9. We already mentioned the changes to the language regime which are, of course, a direct result of the Union's enlargement to 25/27 members. These changes are best understood, however, as changes affecting the Council as a whole, rather than changes of the Council Secretariat. Indeed, the language regime concerns arrangements for meetings of member state representatives such as ministerial councils and working groups. Within the administration of the Secretariat, a more informal and secular trend towards the replacement of French with English as the dominant working language is under way.

\section{References}

Beach, D. (2004). 'The Unseen Hand in Treaty Reform Negotiations: The Role and Influence of the Council Secretariat', Journal of European Public Policy, 11:3, 408-39.

Beach, D. (2005). The Institutional Dynamics of the European Union. London: Palgrave.

Beach, D. (2006). 'Oiling the Wheels of Compromise - The Role and Impact of the Council Secretariat in EU Treaty Reform'. Paper presented at the 47th annual international studies association convention, San Diego, CA, 22-25 March.

Best, E., T. Christiansen and P. Settembri (eds) (2008). The Institutions of the Enlarged European Union-Continuity and Change. Cheltenham: Edward Elgar.

Blyth, M. (2003). 'Structures Do Not Come with an Instruction Sheet: Interests, Ideas, and Progress in Political Science', Perspectives on Politics, 1:4, 695-706.

Bulmer, S., and W. Wessels (1987). The European Council: Decision-making in European Politics. Basingstoke: Macmillan.

Christiansen, T. (2001). 'Inter-institutional Relations and Intra-institutional Politics in the EU:

Towards Coherent Governance?', Journal of European Public Policy, 8:5, 747-69.

Christiansen, T. (2002). 'Out of the Shadows: The General Secretariat of the Council of Ministers', The Journal of Legislative Studies, 8:4, 80-97.

Christiansen, T., and C. Reh (forthcoming). Constitutionalising the European Union. Basingstoke: Palgrave Macmillan.

Collier, R.B., and D. Collier (1991). Shaping the Political Arena. Princeton: Princeton UP.

Council of the European Union (1999). Operation of the Council with an Enlarged Union in Prospect. Report by the Working Party set up by the Secretary-General of the Council. Brussels, 10 March 1999 (SN 21139/99).

Council of the European Union (2003) Suggestions for Procedures for Coherent, Comprehensive EU Crisis Management. Doc. 11127/03, Brussels 3 July.

Council of the European Union (2004). 'Council Decision of 22 March 2004 adopting the Council's Rules of Procedure', Official Journal, L 106/22, 15 April.

Council of the European Union (2004). Report from the Deputy Secretary General on the Management of the General Secretariat. Brussels, 1 October.

Council of the European Union (2006). Council Guide. I. The Presidency Handbook. Luxembourg: Office for Official Publications of the EC.

Council of the European Union (2007). Mission Statement of the General Secretariat of the Council. 
'Decision 80/918/EEC, Euratom, ECSC of 26 September 1980', Official Journal, No. L 261, 4 October 1980.

Deloche-Gaudez, F. (2004). 'Le Secrétariat de la Convention européene: un acteur influent', Politique Européenne, 3:1, 43-67.

Dinan, D. (1999). Ever Closer Union: An Introduction to European Integration. Palgrave: New York.

Duke, S., and S. Vanhoonacker (2006). 'Administrative Governance in CFSP: Development and Practice', European Foreign Affairs Review, 11:2, 163-82.

Egeberg, M. (2006). 'Europe's Executive Branch of Government in the Melting Pot - An Overview', in M. Egeberg, Multilevel Union Administration. The Transformation of Executive Politics in Europe. Basingstoke: Palgrave Macmillan.

Elgstrøm, O., ed. (2003). European Union Council Presidencies. A Comparative Perspective. London: Routledge.

'EU Crisis Response Capability Revisited' (2005). Europe Report, No. 160, 17 January.

Galloway, D. (2001). The Treaty of Nice and Beyond-Realities and Illusions of Power in the EU. Sheffield: Sheffield University Press.

Hall, P., and R. Taylor (1996). 'Political Science and the Three Institutionalisms', Political Studies, 44:4, 936-57.

Hall, P., and R. Taylor (1998). 'The Potential of Historical Institutionalism: A Response to Hay and Wincott', Political Studies, 46:6, 958-62.

Hamlet, L. (2006). Delegation, Information and Supranational Entrepreneurship: The Use of the Council Secretariat by New EU Members. Paper presented at the Annual Meeting of the International Studies Association, San Diego, USA.

Hay, C., and D. Wincott (1998). 'Structure, Agency and Historical Institutionalism', Political Studies, 46:5, 951-7.

Hayes-Renshaw, F., and H. Wallace (2006). The Council of Ministers. London: Palgrave Macmillan.

Hinnfors, J. (1999). 'Stability through Change: The Pervasiveness of Political Ideas', Journal of Public Policy, 19:3, 293-312.

Howorth, J. (2001). 'European Defence and the Changing Politics of the EU: Hanging Together or Hanging Separately?', Journal of Common Market Studies, 39:4, 765-89.

Jachtenfuchs, M. (1997). 'Conceptualising European Governance', in K.E. Jørgensen (ed.), Reflective Approaches to European Governance. London: Macmillan, 39-50.

Juncos, A.E., and K. Pomorska (2007). 'The Deadlock that never Happened: The Impact of Enlargement on the Common Foreign and Security Working Groups', European Political Economy Review, 6, 4-30.

Kay, A. (2005). 'A Critique of the Use of Path Dependency in Policy Studies', Public Administration, 83:3, 553-71.

Kirchner, E. (1992). Decision-making in the European Community: The Council Presidency and European Integration. Manchester: Manchester University Press.

Lewis, J. (2006). Where Informal Rules Rule: The Role of the Council General Secretariat and Presidency in Everyday EU Decision Making. Paper presented at the annual meeting of the International Studies Association, San Diego, USA.

Mangenot, M. (2002). 'L'affirmation du Secrétariat du Conseil de l'Union européenne : les transformations du rôle d'une institution non codifiée'. Paper presented at the 'VIIe congrès de l'Association française de science politique. Lille, 18-21 September.

Mangenot, M. (2003a). 'Une 'chancellerie du prince'. Le Secrétariat général du Conseil dans le processus de decision bruxellois', Politique Européenne, 11, 123-42.

Mangenot, M. (2003b). 'Gouverner l'Union européenne. L'institutionnalisation du Secrétariat general du Conseil', in R. Dehousse and Y. Surel (eds.), Institutionnalisation de l'Europe. Paris: L'Harmattan.

March, J., and J. Olson (1989). Rediscovering Institutions. New York: The Free Press.

Missiroli, A. (2003). 'Euros for ESDP: Financing EU Operations', Occasional Paper, 45. Paris: EU Institute for Security Studies. 
Nuttall, S.J. (1992). European Political Cooperation. Oxford: Oxford University Press.

Nuttall, S.J. (2000). European Foreign Policy. Oxford: Oxford University Press.

Pierson, P., and T. Skocpol (2000). 'Historical Institutionalism in Contemporary Political Science'. Paper presented at the 2000 American Political Science Association annual conference. Washington, DC.

'Règlement intérieur provisoire pour le Conseil Spécial de Ministres de la Communauté du charbon et de l'acier' (1967), in L.J. Brinkhorst and R.H. Lauwaars, Verdrag tot de oprichting van de Europese Gemeenschap voor Kolen en Staal. Zwolle: Tjeenk Willink, 277-8.

Rosamond, B. (2000). Theories of European Integration. London: Palgrave.

Sanchez da Costa Pereira, P. (1988). 'The Use of a Secretariat', in A. Pijpers, E. Regelsberger and W. Wessels (eds.), European Political Cooperation in the 1980s. A Common Foreign Policy for Western Europe. Dordrecht: Kluwer Academic Publishers.

Schout, A., and S. Vanhoonacker (2006). 'Evaluating Presidencies of the Council of the EU. Revisiting Nice', Journal of Common Market Studies, 44:5, 1051-77.

Shackleton, M. (2006). 'The European Parliament', in J. Peterson and M. Shackleton (eds.), The Institutions of the European Union. Oxford: Oxford University Press.

Sherrington, P. (2000). The Council of Ministers - Political Authority in the European Union. London and New York: Pinter.

Spence, D. (2006). 'The Commission and the Common Foreign and Security Policy', in D. Spence with G. Edwards (eds.), The European Commission. London: John Harper.

Tallberg, J. (2003). 'The Agenda-shaping Powers of the EU Council Presidency', Journal of European Public Policy, 10:1, 1-19.

Tallberg, J. (2006). The Power of the Chair: Formal Leadership in International Cooperation. Paper presented at the Third Pan-European Conference in EU Politics, Istanbul, 21-23 September 2006.

Thelen, K. (1999). 'Historical Institutionalism in Comparative Politics', Annual Review of Political Science, 2, 369-404.

Thelen, K., and S. Steinmo (1992). 'Historical Institutionalism in Comparative Perspective', S. Steinmo, K. Thelen and F. Longstreth, Structuring Politics. Cambridge: Cambridge University Press.

Trondal, J. (2006). 'Governing at the Frontier of the European Commission: The Case of Seconded National Officials', West European Politics, 29, 146-60.

Vanhoonacker, S. (forthcoming). 'Co-ordination Challenges in ESDP', in H. Kassim, A. Menon and B.G. Peters (eds.), Coordinating the European Union: Constructing Coordination and Coherent Action in a Multilevel System. Oxford: Oxford UP.

Vanhoonacker, S., and H. Dijkstra (2006). 'Het EU Raadssecretariaat en het Europese Buitenlandsbeleid: Meer dan een griffier', Internationale Spectator, 60:12, 636-41.

Werts, J. (1992). The European Council. Amsterdam: North Holland.

Westlake, M., and D. Galloway (2004), The Council of the European Union. London: John Harper. 